\title{
Spontaneous suprachoroidal haemorrhage with exudative retinal detachment in pregnancy-induced hypertension
}

\author{
Koushik Tripathy, ${ }^{1}$ Rohan Chawla, ${ }^{2}$ Vineet Mutha, ${ }^{3}$ Harathy Selvan ${ }^{4}$
}

${ }^{1}$ Dr Rajendra Prasad Centre for Ophthalmic Sciences, All India Institute of Medical Sciences, New Delhi, India

${ }^{2}$ Dr Rajendra Prasad Centre for Ophthalmic Sciences, All India Institute of Medical Sciences, New Delhi, India

${ }^{3}$ Dr Rajendra Prasad Centre for Ophthalmic Sciences, All India Institute of Medical Sciences, New Delhi, India

${ }^{4}$ Dr Rajendra Prasad Centre for Ophthalmic Sciences, All India Institute of Medical Sciences, New Delhi, India

\section{Correspondence to Dr Rohan Chawla,} dr.rohanrpc@gmail.com

Accepted 9 February 2018

\section{DESCRIPTION}

A 35 -year-old woman at 26 weeks' gestation presented with vision loss in the right eye (RE) and abdominal pain for 10 days. There was no fever. $\mathrm{RE}$ had conjunctival congestion and chemosis with a visual acuity of finger counting close to face. The RE showed an exudative retinal detachment, disc oedema and choroidal detachment (figure 1 ). The left eye visual acuity was $6 / 12$ and on examination there was disc oedema, cotton wool spots, subfoveal fluid and Elschnig's spots (figure 2). ${ }^{1}$ Ultrasonogram showed echoes beneath the choroidal detachment suggestive of suprachoroidal haemorrhage (figure 3). Intraocular pressure and anterior chamber depth were normal in either eye. The blood pressure (BP) was 200/120 mm Hg. The laboratory investigations included a haemoglobin of $6.7 \mathrm{~g} / \mathrm{dL}(12-15.8 \mathrm{~g} / \mathrm{dL})$, platelet count $65 \times 10^{9} / \mathrm{L} \quad\left(150 \times 10^{9}-300 \times 10^{9} / \mathrm{L}\right)$, total leucocyte count $9.5 \times 10^{9} / \mathrm{L}\left(4 \times 10^{9}-11 \times 10^{9} / \mathrm{L}\right)$, total protein $4.8 \mathrm{~g} / \mathrm{dL}(6.7-8.6 \mathrm{~g} / \mathrm{dL})$, serum glutamic-oxaloacetic transaminase $29 \mathrm{U} / \mathrm{L}(12-38 \mathrm{U} / \mathrm{L})$, serum glutamic-pyruvic transaminase $13 \mathrm{U} / \mathrm{L}$ (7-41 U/L), urea $108 \mathrm{mg} / \mathrm{dL}(15-40 \mathrm{mg} / \mathrm{dL})$ and creatinine $6.8 \mathrm{mg} / \mathrm{dL}(0.6-1.2 \mathrm{mg} / \mathrm{dL})$. Abdominal ultrasound revealed intrauterine fetal death and a gallbladder stone. The patient needed intravenous labetalol, nitroglycerine and oral antihypertensives for control of BP. Systemic management included haemodialysis, blood transfusions, intravenous antibiotics and medical termination of pregnancy, following which the medical condition was stabilised. At 2 months' follow-up, the patient

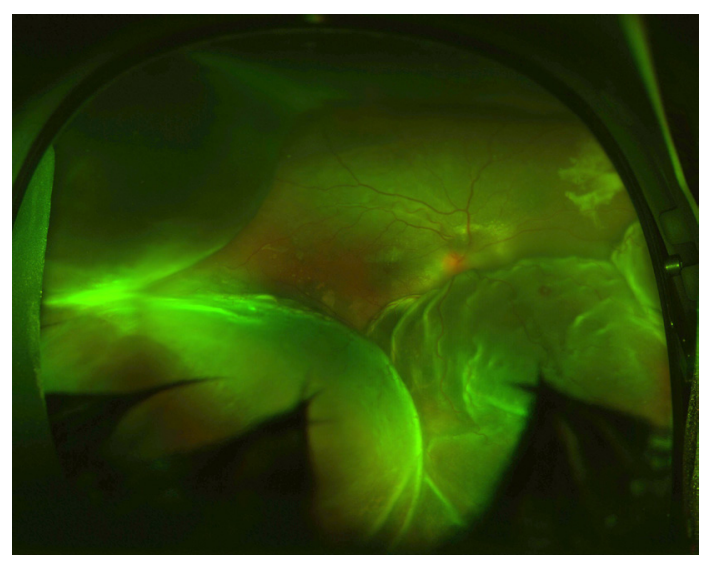

Figure 1 The ultrawide fundus image shows disc oedema, mounds of choroidal detachment and an inferior bullous exudative retinal detachment in the right eye.

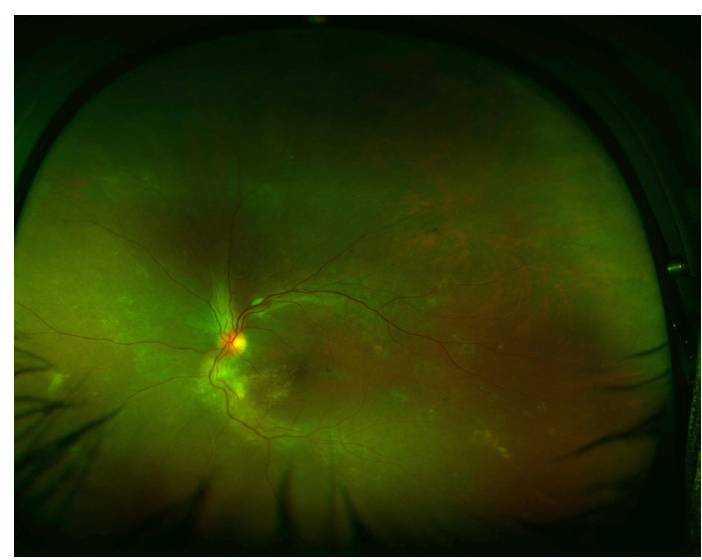

Figure 2 The left eye showed papilledema, cotton wool spot superotemporal to the optic disc, hard exudates inferotemporal to the optic disc and Elschnig's spots in the temporal retina.

had a vitreous haemorrhage (vision RE - hand movements close to face) in RE but the ocular ultrasound did not show any choroidal or retinal detachment. The left eye had recovered to $6 / 6$. The patient was lost to follow-up.

Spontaneous suprachoroidal haemorrhage (SSCH) is a rare entity and has been known to be associated with anticoagulation therapies (including warfarin, aspirin, clopidogrel, heparin), thrombolytic drugs (streptokinase, tissue plasminogen activator), blood dyscrasias, haemodialysis and Valsalva manoeuvre. ${ }^{2}$ Systemic predispositions include hypertension, atherosclerosis, cerebrovascular attack, coronary artery disease, diabetes mellitus, chronic renal failure, hepatic failure and disseminated intravascular coagulation. ${ }^{2}$ Ocular associations are age-related macular degeneration, glaucoma, high myopia and proliferative diabetic retinopathy. ${ }^{2}$ Hypertension alone has been reported

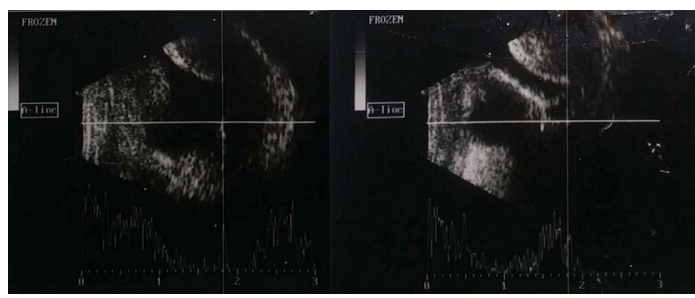

Figure 3 Ultrasound B-scan of the right eye revealed mounds of choroidal detachment with echoes beneath the mounds suggestive of suprachoroidal haemorrhage. 
to cause SSCH with secondary angle closure glaucoma. ${ }^{3}$ Risk factors for SSCH and exudative retinal detachment in our case include pregnancy-induced hypertension (PIH), anaemia, thrombocytopenia, hypoproteinaemia and renal failure. However, control of systemic risk factors resulted in the resolution of the exudative retinal detachment and SSCH. No surgical intervention was planned in view of normal intraocular pressure, the absence of kissing choroidals and deranged systemic status. To the best of our knowledge, an association of SSCH with PIH has not been reported before.

\section{Learning points}

Spontaneous suprachoroidal haemorrhage may occur in pre-eclampsia/eclampsia with thrombocytopenia.

- Control of systemic parameters is of paramount importance in the management of such a disease.
Contributors $\mathrm{KT}, \mathrm{VM}$ and $\mathrm{HS}$ collected the data. $\mathrm{KT}$ and RC wrote the first draft. All authors revised the draft with important intellectual content and approved the final version. All authors agree to be accountable for the work.

Funding This research received no specific grant from any funding agency in the public, commercial or not-for-profit sectors.

Competing interests None declared.

Patient consent Obtained.

Provenance and peer review Not commissioned; externally peer reviewed.

(C) BMJ Publishing Group Ltd (unless otherwise stated in the text of the article) 2018. All rights reserved. No commercial use is permitted unless otherwise expressly granted.

\section{REFERENCES}

1 Tripathy K, Chawla R. Bilateral exudative retinal detachment with choroidopathy in malignant hypertension. Natl Med J India 2015;28:261.

2 Hsiao SF, Shih MH, Huang FC. Spontaneous suprachoroidal hemorrhage: case report and review of the literature. Taiwan J Ophthalmol 2016;6:36-41.

3 Fukuchi T, Suda K, Matsuda $\mathrm{H}$, et al. Secondary acute angle closure with spontaneous suprachoroidal hemorrhage suspected by ultrasound biomicroscopic examination. Jpn J Ophthalmol 2009;53:661-3.

Copyright 2018 BMJ Publishing Group. All rights reserved. For permission to reuse any of this content visit http://group.bmj.com/group/rights-licensing/permissions.

BMJ Case Report Fellows may re-use this article for personal use and teaching without any further permission.

Become a Fellow of BMJ Case Reports today and you can:

- Submit as many cases as you like

- Enjoy fast sympathetic peer review and rapid publication of accepted articles

- Access all the published articles

- Re-use any of the published material for personal use and teaching without further permission

For information on Institutional Fellowships contact consortiasales@bmjgroup.com

Visit casereports.bmj.com for more articles like this and to become a Fellow 